\title{
Evaluasi Kelayakan Bisnis Restoran Ma'Kerang Bandung
}

\author{
Indria Andianie ${ }^{\mathbf{1}}$, Eeng Ahman ${ }^{2}$, Indriyani Handyastuti ${ }^{3}$ \\ ${ }^{1}$ Manajemen Industri Katering, Fakultas Pendidikan Ilmu Pengetahuan Sosial, Universitas \\ Pendidikan Indonesia, Jl. Dr. Setiabudhi No. 229, Bandung 40154, Indonesia \\ ${ }^{2}$ Manajemen Bisnis, Fakultas Pendidikan Ekonomi dan Bisnis, Universitas Pendidikan \\ Indonesia, Jl. Dr. Setiabudhi No. 229, Bandung 40154, Indonesia \\ ${ }^{3}$ Meeting Insentif Conference Exhibition, Sekolah Tinggi Pariwisata Bandung, Jl. Dr. \\ Setiabudi No.186, Hegarmanah, Kec. Cidadap, Kota Bandung, Jawa Barat 40141
}

* Koresponding Penulis. E-mail: indriaandianie@student.upi.edu (Indria Andianie)

\begin{abstract}
Abstrak
Penelitian ini bertujuan untuk mengetahui kelayakan bisnis pada restoran Ma'kerang yang ditinjau dari aspek pasar dan pemasaran, manajemen, teknis/operasi, hukum, ekonomi sosial dan keuangan.Metode yang digunakan adalah metode kuantitatif, untuk aspek pasar menggunakan segmentasi, pasar target dan posisi pasar dan pemasaran menggunakan bauran pemasaran 7P (Product, price, place, promotion, people, physical evidence, process). Aspek manajemen menggunakan perencanaan, pengorganisasian, pelaksaan dan pengawasan. Aspek teknis/operasi dengan menggunakan penilaian lokasi area produksi, luas area produksi, dan tata letak area produksi. Aspek hukum dengan menggunakan penilaian badan hukum, izin-izin yang dimiliki, dan sertifikat tanah. Aspek ekonomi sosial menggunakan penilaian dampak ekonomi dan dampak sosial. Aspek keuangan dengan menggunakan metode penilaian investasi. Berdasarkan hasil penelitian dengan wawancara pemilik, manajer, karyawan, wargasekitar, kuesioner dan observasi menjelaskan bahwa aspek pasar sudah baik karena dalam segmentasi, pasar target, dan posisi pasar Ma'kerang sudah jelas. Dan hasil penilaian pemasaran mengenai 7P (Product, price, place, promotion, people, physical evidence, process) berada pada kategoricukup baik dan layak untuk dijalankan. Aspek manajemen layak untuk dijalankan karena Ma'kerang memiliki perencanaan, pengorganisasian, pengawasan dan pelaksanaan dalam operasional sudah baik. Aspek teknis/operasi tidak layak karena hasil penilaian luas produksi dan tata letak produksi tidak luas dan penataan peralatan belum tertata rapih.Aspek hukum tidak layak karena Ma'kerang belum memiliki izin usaha dari pemerintah. Aspek ekonomi sosial layak karena Ma'kerang tidak memberikan dampak yang negatif untuk warga sekitar. Aspek keuangan dengan indikator penilaian investasi bahwa payback period3 bulan 8 hari maka usaha layak untuk dijalankan Net present value (NVP) 34,514,085 $>40,520,500$ sehingga tidak dapat diterima dan tidak layak, Internal rate of return (IRR) $67 \%>5,25 \%$ sehingga layak untuk diteruskan, dan Profitability Index (PI) $1.839>1$ sehinggadapat diterima dan layak.Berdasarkan hasil penelitian saran dari penulis Ma'kerang harus bisa mempertahankan kualitas produk, terus memberikan promosi yang menarik agar dapat menarik konsumen. Manajer Ma'kerang harus selalu memberikan pengarahan kepada karyawan agar pekerjaan lebih terarah. Lokasi produksi Ma'kerang harus diperluas dan lebih ditata dengan rapi. Dan Ma'kerang harus membuat izin usaha kepada pemerintah.
\end{abstract}

Kata Kunci: Kelayakan bisnis; Restoran; Ma'kerang

\section{Pendahuluan}

Kuliner merupakan kata serapan dari bahasa Inggris yaitu culinary yang berarti berhubungan dengan memasak (Alamsyah, 2008:1). Soal kuliner menurut Suganda
(2011:189) Bandung merupakan urutan kedua setelah Jakarta. Bandung merupakan salah satu kota yang mempunyai daya tarik bagi pengunjung untuk berwisata seperti halnya icon kota Bandung "kota wisata, kota kreatif, kota belanja, dan kota kuliner"itulah 
penyebab Bandung menjadi tujuan destinasi seluruh wisatawan. Selain memiliki objek wisata yang menarik, Bandung juga terkenal banyaknya tempat kuliner yang menarik.

Bandung memiliki ciri khas kuliner seperti baso tahu, siomay, pisang molen, cireng, colenak, bajigur, es cendol, seblak hingga makanan khas dan unik lainnya (Hidayat, Triyani dan Hanifah 2009:8). Masyarakat Bandung memang tidak ada habisnya untuk berkreatifitas dalam membuat makanan baru, sehingga banyak sekali yang tertarik untuk menjalankan bisnis kuliner, mulai dari yang menengah ke bawah seperti membuka rumah makan menggunakan tenda, hingga menengah keatas yang sering disebut restoran.

Restoran merupakan suatu bangunan atau tempat yang menjual makanan dan minuman disertakan pelayanan yang baik diberikan kepada pelanggan secara komersial (Marsum, 2005:7).Karena dilihat dari pembangungan restoran yang semakin menjamur. Berbagai jenis restoran baru muncul menawarkan aneka produk yang menarik dan fasilitas restoran yang beraneka ragam. Karena perkembangan jaman saat ini restoran bukan sekedar tempat untuk makan dan minum, tetapi sebagai tempat terbuka untuk kegiatan seperti acara spesial ulang tahun, pernikahan bahkan sekarang ini biasanya restoran di jadikan tempat untuk kegiatan seperti rapat bisnis.

Salah satu restoran yang berada di kota Bandung adalah Ma'kerang yang berlokasi di Jalan Malabar, Ma'kerang mulai beroperasional sejak bulan Juni 2016. Ma'kerang cukup menarik untuk diteliti karena awalnya Ma'kerang beroperasional terinspirasi oleh restoran yang sudah lebih lama beroperasional yaitu Kerang Ajaib yang menjual aneka kerang rebus yang diberikan sambal cocol. Ma'kerang tidak asal mengikuti saja, tetapi Ma'kerang juga berinovasi lain dengan menjual aneka kerang yang diberikan bumbu rempah special dengan pilihan level kepedasan, dan menu yang ditawarkan oleh Ma'kerang juga lebih banyak, variatif dan mengikuti trend yang memang sedang disukai oleh konsumen.

Ma'kerang bisa memberikan dampak yang positif untuk wilayah sekitar karena selain membuka lapangan pekerjaan untuk masyarakat sekitar, Ma'kerang juga memberikan inspirasi masyarakat sekitar. Karena melihatnya banyak pengunjung yang sering datang ke wilayah jalan malabar membuat masyarakat sekitar membuka usaha juga seperti menjual nasi goreng dan bubur. Pihak Ma'kerang merasa tidak keberatan dengan itu semua dan tidak menganggap mereka menjadi pesaing, karena dari menu yang ditawarkan pun berbeda.

Dilihat dari data pendapatan Ma'kerang mengalami kenaikan setiap bulannya sampai bulan Desember 2016. Bahkan di bulan Desember 2016 mulai dari tanggal 3 pendapatannya sudah bisa mencapai paling besar adalah $\mathrm{Rp}$. 5,952,100- Rp. 6,003,300 dan pendapatan terkecilnya adalah Rp. 1,116,300. Tetapi di bulan Januari Ma'kerang mengalami penurunan pendapatan sebesar $\mathrm{Rp}$. 14,682,750, dan dari bulan Januari ke Februari mengalami penurunan pendapatan lagi sebesar Rp. 5,745,125.

Menurut pemilik Ma'kerang pendapatan Ma'kerang cukup besar sehingga pemilik Ma'kerang ingin membuat cabang baru di tempat yang lebih strategis, karena di tempat yang tidak begitu strategis saja sudah bisa menarik pengunjung yang banyak. Oleh karena itu pemilikMa'kerang ingin meningkatkan lagi pemasaran. Selain ingin meningkatkan pemasaran, pemilik Ma'kerang ingin memperbaiki dan meningkatkan sumber daya manusia, kinerja karyawan cukup baik namun masih ada karyawan Ma'kerang yang tidak mentaati peraturan yang berlaku di Ma'kerang seperti masih ada karyawan yang datang terlambat dan masih ada karyawan yang makan tidak membayar, padahal karyawan Ma'kerang diberikan kebijakan mendapat diskon $30 \%$ jika ingin makan produk yang dijual Ma'kerang. 
Karena pemaparan di atas dan melihat besarnya peluang Ma'kerang dengan pendapatan yang besar memang memiliki peluang ma'kerang untuk mengembangkannya. Tetapi sebelumnya tentu saja harus dipertimbangkan terlebih dahulu karena bisnis ma'kerang ini belum berjalan lama, baru 8 bulan beroperasional dan belum mengetahui apa saja yang perlu di perbaiki dan perlu di tingkatkan. Maka dari itu penulis kiranya menganggap perlu melalukan kelayakan bisnis.

\section{Metode Penelitian}

\subsection{Objek Penelitian}

Penelitian ini dilaksanakan di Ma'kerang yang beralamat di Jl. Malabar No 15 Bandung. Ma'kerang ini telah berdiri selama enam bulan bulan sejak Juli 2016 2016. Ma'kerang adalah restoran yang menyediakan berbagai jenis kerang dan aneka seafood lainnya seperti udang, cumi dan kepiting yang diberi bumbu rempah. Dikarenakan tidak semua orang bisa makan/alergi dengan seafood Ma'kerang juga menyediakan makanan jenis lainnya seperti chicken wings, aneka mie, ceker. Semua makanan yang tersedia bisa diberikan level kepedasan.

\subsection{Sampel}

Menurut Tika (2006:33) Sampel adalah bagian dari suatu objek atau subjek yang mewakili populasi. Pengambilan sampel harus sesuai dengan kualitas dan karakteristik suatu populasi. Pengambilan sampel yang tidak sesuai dengan kualitas dan karakteristik populasi akan menyebabkan suatu penelitian menjadi tidak dapat dipercaya dan kesimpulannya pun bisa keliru. Hal ini karena tidak dapat mewakili populasi.

\subsubsection{Sampel Kuesioner}

Untuk menghitung jumlah sampel kuesioner pada penelitian ini dengan menggunakan populasinya adalah konsumen Ma'kerang. Pada periode 2 Desember 2016 sampai 8 Desember 2016 jumlah konsumen adalah 709 Orang. Maka pengambilan sampel dilakukan dengan menggunakan rumus slovin (Umar $\mathrm{H}$. , 2003:141) yaitu:

$$
\mathrm{n}=\frac{N}{1+N(e)^{2}}
$$

Dimana :

$$
\begin{aligned}
\mathrm{n}= & \text { Jumlah sampel } \\
\mathrm{N}= & \text { Populasi } \\
\mathrm{e}= & \text { Presentase kelonggaran } \\
& \text { ketidak telitian }(10 \%) \\
& \text { responden dari populasi }(\mathrm{N}) \\
& =709 \\
\mathrm{n}= & 709 /\left(1+709(0.1)^{\wedge} 2\right) \\
= & 87,6=88
\end{aligned}
$$

Jadi berdasarkan perhitungan dari jumlah populasi sebanyak 709 , dengan tingkat kesalahan $10 \%$ yang di konversi menjadi 0,1 maka responden yang harus diperoleh adalah sebanyak 88 responden.

\subsubsection{Sampel Wawancara Karyawan}

Cara menentukan jumlah sampel yang akan di wawancara untuk karyawan menggunakan teknik sampling jenuh dan karena jumlah karyawan Ma'kerang ada 12 orang, maka penulis melakukan wawancara dengan 12 orang karyawan.

\subsubsection{Sampel Wawancara Pemilik dan Manajer}

Cara menentukan jumlah sampel wawancara Pemilik dan Manajer dengan menggunakan teknik sampling jenuh. Dan karena jumlah pemilik dan manajer Ma'kerang hanya ada satu. Maka jumlah sampel wawancara pemilik dan manajer adalah 1 pemilik dan 1 manajer.

\subsubsection{Sampel Wawancara Masyarakat sekitar}

Karena teknik sampel wawancara masyarakat sekitar menggunakan teknik snowball, maka jumlah sampel pada wawancara Masyarakat belum bisa diketahui karena hanya dapat diketahui dan tergantung dari rujukan setelah penulis melakukan wawancara tersebut. 


\section{Hasil dan Pembahasan}

\subsection{Pasar dan Pemasaran}

\subsubsection{Pasar}

Hasil wawancara dan analisis dalam hal pasar Ma'kerang sudah memiliki segmentasi pasar geographis, demographis, psikographis, dan perilaku yang sudah jelas. Sehingga dalam segmentasi pasar Ma'kerang hanya perlu fokus pada tujuan yang sudah dibuat. Dalam pasar target Ma'kerang sudah memiliki target dan kategori pasar sasaran yang memilih pemasaran serba aneka, sehingga target pasar Ma'kerang bisa dikatakan jelas. Dan mengenai posisi pasar karena Ma'kerang masih restoran kecil dan belum beroperasional lama Ma'kerang untuk saat ini hanya bermain di market follower karena lebih memilih mengikuti strategi market leader daripada melawan.

\subsubsection{Pemasaran}

Hasil kuesioner dan observasi dari analisis pemasaran $7 \mathrm{P}$ adalah sebagai berikut :

a. Produk

Cita rasa dari produk Ma'kerang dapat disimpulkan bahwa produk Ma'kerang bisa dikatakan enak karena $61 \%$ respoden menyatakan produk Ma'kerang enak. Dan berdasarkan hasil observasi produk Ma'kerang memang rasanya enak, bumbunya meresap dan berbeda dari restoran lain karena pedasnya bisa disesuaikan dengan keinginan setiap konsumen.

Penampilan produk Ma'kerang dapat disimpulkan bahwa 56\% responden mengatakan penampilan produk Ma'kerang menarik, dan berdasarkan observasi Ma'kerang memiliki tampilan yang berbeda setiap produknya, ada yang menggunakan tray alumunium, piring cantik dll. Hanya saja setiap produk tidak diberi garnish sehingga tidak begitu menarik.

Aroma produk Ma'kerang dapat disimpulkan bahwa 52\% responden menyatakan aromanya enak, dan hasil observasi juga menyatakan bahwa aroma produk Ma'kerang enak bisa tercium dari jauh dan tidak bau amis.

Kebersihan produk Ma'kerang dapat disimpulkan bahwa bersih karena 61\% responden menyatakan bersih, dan berdasarkan hasil observasi memang produk yang ditawarkan Ma'kerang bersih dan penyajiannya juga bersih.

Kesegaran produk Ma'kerang dapat disimpulkan segar karena $61 \%$ responden menyatakan produk Ma'kerang segar, dan berdasarkan hasil observasi produk Ma'kerang memang segar dan setiap kerang yang di order direbusnya pun secara mendadak sehingga produk Ma'kerang bisa dikatakan segar.

Hasil penelitian mengenai produk Ma'kerang dapat dikatakan baik hanya saja harus dipertahankan dan dikembangkan lagi agar bisa lebih baik lagi.

b. Harga

Harga yang ditawarkan Ma'kerang dapat disimpulkan bahwa $45 \%$ responden menyatakan harga yang ditawarkan Ma'kerang terjangkau. Hasil wawancara dengan karyawan menyatakan harga yang ditawarkan Ma'kerang kisaran harga Rp. 4.000-Rp.120.000. dan berdasarkan hasil observasi penulis bahwa harga yang ditawarkan Ma'kerang terjangkau, karena dengan Rp.50.000,- bisa sudah membeli kerang dara $1 / 4$, makanan ringan seperti ceker, nasi dan minuman.

Daya tarik harga terhadap produk Ma'kerang dapat disimpulkan bahwa 51\% responden menyatakan menarik. Dan hasil observasi menyatakan bahwa memang Ma'kerang memiliki daya tarik harga terhadap produk, produknya enak dan harganya realtif murah jadi bisa dikatakan menarik.

Kesesuaian harga terhadap kualitas produk dapat disimpulkan bahwa 50\% responden menyatakan sesuai, hasil wawancara manajer menyatakan bahwa memang Ma'kerang sudah mempertimbangkan dan menjual menu sesuai dengan kualitas produknya, dan hasil observasi menyatakan sesuai. Jadi memang 
Ma'kerang memiliki kesesuain harga terhadap kualitas produk.

Perbandingan harga Ma'kerang dengan restoran lain dapat disimpulkan 50\% responden menyatakan bahwa harga Ma'kerang lebih murah. Dan berdasarkan hasil observasi harga Ma'kerang memang lebih murah jika dibandingkan dengan salah satu restoran seafood lainnya seperti bakar street. Harga kerang dara 1/4 Ma'kerang Rp. 15.000, harga kerang dara di bakar street 300 gr Rp. 25.000.

Hasil penelitian mengenai harga Ma'kerang dapat dikatakan layak karena harganya terjangkau, memiliki daya tarik harga terhadap produk, memiliki kesesuaian harga terhadap kualitas produk, memiliki harga yang lebih mjurah dibandingkan dengan restoran seafood lainnya.

c. Tempat

Aksesibilitas lokasi Ma'kerang dapat disimpulkan bahwa 52\% responden menyatakan cukup mudah dijankau, dan hasil observasi menyatakan memang lokasi Ma'kerang kurang mudah untuk diakses karena tidak ada kendaraan umum yang langsung lewat depan Ma'kerang, dank arena Ma'kerang berada di satu jalur membuat konsumen yang membawa kendaraan probadi harus memutar jalan cukup jauh.

Visibilitas Ma'kerang dapat disimpulkan bahwa $52 \%$ responden menyatakan cukup mudah dijangkau, dan hasil observasi menyatakan bahwa lokasi Ma'kerang tidak bisa terlihat jelas dari jalan besar dan tidak ada petunjuk tempat di jalan besar.

Lalu lintas (traffic), kepadatan dan kemacetan lalu lintas, tempat parkir, ekspansi, lingkungan, persiangan, dan peraturan pemerintah dapat disimpulkan bahwa lahan tempat Ma'kerang 48\% menyatakan lahan tempat cukup mencukupi. Dan berdasarkan hasil observasi di sekitar Ma'kerang bisa terbilang daerah yang sepi tidak banyak orang yang berlalu-lalang. Hanya ramai saat sore menjelang malam, di jalan Ma'kerang pada saat sore menjelang malam terkadang mengalami kemacetan dan tentu saja menjadi hambatan karena bisa membuat pengunjung malas untuk datang ke Ma'kerang, tempat parkir aman tetapi tidak begitu luas untuk parkir mobil karena hanya bisa menampung sekitar 4 mobil, Ma'kerang memiliki tempat yang cukup untuk perluasan usaha dikemudian hari, daerah sekitar Ma'kerang banyak sekali toko-toko pakaian, supermarket sehingga bisa mendukung Ma'kerang karena jika banyak orang-orang yang pergi ke daerah Malabar untuk berbelanja bisa saja jadi ingin mampir ke Ma'kerang, di wilayah sekitar Ma'kerang tidak ada pesaing, Ma'kerang hanya baru mengikuti peraturan pemerintah non formal yang meminta izin pembangunan restoran kepada ketua RT/RW setempat.

d. Promosi

Promosi Ma'kerang dapat disimpulkan bahwa hanya menggunakan personal selling, mass selling, dan promosi penjualan saja, tidak melakukan public relation dan direct marketing. Karena Ma'kerang menanggap dengan menggunakan personal selling, mass selling, dan promosi penjualan sudah bisa meningkatkan pemasaran dan menarik konsumen yang banyak. Apalagi dengan menggunakan jasa food bloger di instagram sangat membantu pemasaran dan berdasarkan pengamalaman responden, $51 \%$ responden menyatakan mengetahui Ma'kerang dari Mass selling yaitu media online internet.

e. People

People atau karyawan Ma'kerang saat melayani konsumen dapat disimpulkan bahwa karyawan melayani tamu dengan cepat, menyapa tamu dengan ramah, dan karyawan melayani tamu dengan teliti agar tidak terjadi kesalahan seperti salah memesan dan salah mengantarkan pesanan dengan cara mengulang mengucapkan menu apa saja yang di pesan untuk memastikan.

f. Physical Evidence

Desain ekterior Ma'kerang dapat disimpulkam bahwa cukup menarik, dengan 
konsep yang simple bisa membuat konsumen nyaman saat makan dan minum di Ma'kerang tetapi desain interior Ma'kerang lebih menarik lagi karena adanya hiasan lampu gantung dan walpapper yang menarik, seharusnya desain ekterior Ma'kerang lebih di buat nyaman dan menarik lagi karena desain ekterior adalah bagian utama yang akan dilihat oleh konsumen, jika dari luar tampak kurang menarik akan mempengaruhi konsumen tidak ingin datang. Brosur Ma'kerang sangat menarik, walaupun simple tetapi informasi mengenai Ma'kerang sudah tertera jelas, dan menu yang ditawarkan Ma'kerang disertai harga serta gambarnya, dan yang lebih menarik dari brosur Ma'kerang adalah menempelkan voucher diskon sehingga orang yang mendapatkan brosur Ma'kerang akan senang dan kemungkinan tidak akan dibuang. Seragam karyawan Ma'kerang menggunakan warna dan gambar ciri khas dari Ma'kerang yaitu gambar logo Ma'kerang dan dibelakang seragam tertera tulisan "Mengerang!!" yang berarti ajakan untuk memakan kerang.

g. Process

Hasil dari observasi dapat disimpulkan bahwa proses pemesanan menu di Ma'kerang sangat mudah sekali, karena saat konsumen datang tinggal duduk saja menunggu pelayan datang dan tinggal memesan menu apa saja yang akan dibeli dan menunggu makanan di antarkan, untuk pembayarannya saat pulang bisa langsung membayar di kasir. Waktu proses pembuatan Ma'kerang tidak terlalu cepat karena konsumen bisa menunggu sampai 15 menit untuk makanan datang

\subsection{Manajemen}

\subsubsection{Perencanaan}

Perencanaan pemasaran Ma'kerang masih akan menggunakan jasa food blogger, karena manajer Ma'kerang menganggap menggunakan jasa food blogger sangat mempengaruhi pengunjung banyak yang datang. Hasil wawancara manajer dan seluruh karyawan Ma'kerang dapat disimpulkan bahwa Ma'kerang memang memiliki perencanaan produk, Ma'kerang membuat menu baru agar konsumen tidak bosan. Hanya saja waktu dari perencanaan pembuatan produk waktunya tidak pasti. Perencanaan sumber daya manusia dapat disimpulkan bahwa Ma'kerang untuk mengembangkan sdm manajer memberikan pelatihan seperti mengajarkan cara komunikasi yang baik dengan tamu, dan juga memberikan pelatihan seperti memasak untuk waiter dan kasir.

\subsubsection{Pengorganisasian}

Pendelegasian wewenang Ma'kerang dapat disimpulkan bahwa jika manajer tidak ada setiap karyawan tidak boleh langsung mengambil tindakan tetapi harus langsung memberitahukan jika ada masalah di grup line, sehingga manajer langsung mengetahui dan dapat langsung memberikan arahan. Dan setiap pergantian shift karyawan selalu melakukan pendelegasian seperti memberitahu pekerjaan apa saja yang belum dikerjaan dan memberitahukan barang apa saja yang sudah habis pada saat pergantian shift. Pembagian kerja di Ma'kerang dapat disimpulkan bahwa jumlah karyawan di Ma'kerang ada 12 dan sudah mencukupi tetapi karyawan terkadang tidak berkerja sesuai denggan pekerjaannya karena setiap karyawan di coba untuk bisa di segala bidang, misalnya waiter harus bisa juga memasak. Berdasarkan hasil wawancara karyawan mengenai keadilan pembagian pekerjaan, sebagian besar karyawan menyatakan bahwa tidak adil karena ada yang bekerja banyak dan ada yang tidak bekerja banyak.

\subsubsection{Pelaksanaan}

Pengarahan sumber daya manusia Ma'kerang dapat disimpulkan bahwa manajer Ma'kerang selalu memberikan arahan dan jika manajer tidak ada di tempat biasanya memberikan arahan kepada karyawan di grup line. Tetapi setelah konfirmasi karyawan sebagian besar karyawan menyatakan bahwa tidak mendapatkan pengarahan dari manajer. 


\subsubsection{Pengawasan}

Pengawasan sdm Ma'kerang dapat disimpulkan bahwa manajer Ma'kerang selalu mengawasi karyawan contohnya manajer mengawasi dan mencatat karyawan yang rajin dan tidak untuk pertimbangan pemberian bonus. Dan berdasarkan konfirmasi hasil wawancara dengan karyawan bahwa semua karyawan menyatakan terkadang diawasi seperti diperhatikan saat bekerja dan terkadang tidak diawasi. Pengawasan anggaran di Ma'kerang dapat disimpulkan bahwa manajer menyatakan selalu mengawasi anggar biaya karena soal keuangan sangat penting. Biasaya mengawasi biaya keluar dan masuk saja, apakah mengalami keuntungan atau tidak. Dan berdasarkan konfirmasi hasil wawancara dengan karyawan bahwa semua karyawan menyatakan tidak mengetahui kalau manajer mengawasi anggaran. Pengawasan kualitas produk di Ma'kerang dapat disimpulkan bahwa manajer menyatakan bahwa selalu memerintahkan karyawan untuk mengawasi kualitas produk seperti sebelum diberikan kepada konsumen karyawan harus mencobanya terlebih dahulu untuk memastikan bahwa kualitas produk baik. Dan berdasarkan konfirmasi hasil wawancara dengan karyawan menyatakan bahwa semua karyawan diperintahkan untuk mengawasi produk sebelum diberikan kepada konsumen.

\subsection{Aspek Teknis dan Operasi}

\subsubsection{Penilaian Lokasi Produksi}

Hasil penelitian penilaian lokasi produksi dapat disimpulkan bahwa lokasi produksi Ma'kerang tidak begitu luas dan kurang tertata. Lokasi produksi adalah lokasi yang penting karena jika tidak bisa membuat karyawan leluasa akan menghambat proses produksi.

\subsubsection{Luas Produksi}

Luas produksi Ma'kerang dapat disimpulkan bahwa luas produksi
Ma'kerang adalah $5 \mathrm{mx} 3 \mathrm{~m}$ dan sebagian besar karyawan menyatakan bahwa luas produksi belum cukup dan membuat karyawan kurang leluasa saat bekerja.

\subsubsection{Tata Letak Produksi}

Tata letak produksi Ma'kerang dapat disimpulkan bahwa kurang optimal dan sebagian karyawan menyatakan bahwa pemakaian ruang produksi belum efisien karena sempit. Dan berdasarkan hasil observasi tata letak produksi belum begitu baik karena kurang luas, penataan peralatan kurang rapih dan toilet pelanggan seharusnya tidak berada di dalam kitchen.

\subsubsection{Kelengkapan Peralatan}

Kelengkapan peralatan Ma'kerang dapat disimpulkan bahwa semua karyawan menyatakan peralatan untuk operasional sudah lengkap dan memadai, dan berdasarkan hasil observasi memang peralatan untuk operasional di Ma'kerang sudah memadai.

\subsection{Aspek Hukum}

Hasil wawancara pemilik Ma'kerang dan observasi dapat disimpulkan bahwa Ma'kerang dalam aspek hukum tidak layak karena belum memiliki surat izin usaha dari pemerintah dan izin yang dimiliki baru izin $\mathrm{RT} / \mathrm{RW}$ setempat.

\subsection{Ekonomi Sosial}

\subsubsection{Peningkatan Ekonomi Warga Sekitar}

Hasil wawancara manajer dan 10 warga sekitar dapat disimpulkan bahwa memang Ma'kerang memperkerjakan 2 warga sekitar, tetapi berdasarkan hasil wawancara denga warga sekitar sebagian besar menyatakan denga berdirinya Ma'kerang tidak mempengaruhi peningkatan ekonomi warga.

\subsubsection{Meningkatkan Ekonomi Pemerintah}

Hasil wawancara manajer dan observasi Ma'kerang belum bisa meningkatkan ekonomi pemerintah karena sampai saat ini Ma'kerang belum memiliki 
izin usaha dan belum terkena pajak.

\subsubsection{Adanya Perubahan Demografi}

Dengan berdirinya Ma'kerang dapat disimpulkan bahwa Ma'kerang belum melakukan apa-apa untuk warga sekitar dan berdasarkan hasil wawancara warga sekitar dengan berdirinya Ma'kerang sebagian besar menyatakan memang tidak mempengaruhi perubahan geografi.

\subsubsection{Perubahan Budaya}

Ma'kerang baru beroperasional 6 bulan sehingga tidak membuat perubahan budaya untuk warga sekitar. Dan berdasarkan hasil wawancara dengan warga sekitar sebagian besar warga menyatakan bahwa memang dengan berdirinya Ma'kerang tidak mempengaruhi perubahan budaya.

\subsubsection{Perubahan Kesehatan Masyarakat}

Ma'kerang tidak mempengaruhi perubahan kesehatan warga karena Ma'kerang selalu menjaga kebersihan dan selalu membuang langsung limbah ke tpa. Dan berdasarkan hasil wawancara dengan warga sebagian besar warga menyatakan bahwa memang dengan berdirinya Ma'kerang tidak mempengaruhi kesehatan bagi warga sekitar.

Tabel 1. Aspek Keuangan

\begin{tabular}{clcc}
\hline No & \multicolumn{1}{c}{ Metode } & Hasil & Keterangan \\
\hline 1 & Payback period & 3 bulan 80 hari & Layak \\
2 & Net present value (NVP) & $34,514,085>40,520,500$ & Tidak Dapat diterima, dan \\
& & & tidak Layak \\
3 & Internal rate of return (IRR) & $67 \%>5,25 \%$ & Layak untuk diteruskan \\
4 & Profitability Index (PI) & $1,839>1$ & Dapat diterima dan Layak \\
\hline
\end{tabular}

\section{Kesimpulan}

Kelayakan bisnis Ma'kerang ditinjau dari aspek pasar dan pemasaran, penilaian aspek pasar Ma'kerang sudah baik karena dalam segmentasi, pasar target, dan posisi pasar Ma'kerang sudah jelas. Penilaian bauran pemasaran mengenai produk, harga, tempat, promosi, people, physical evidence, dan process Ma'kerang berada pada katogori cukup baik dan layak untuk dilanjutkan, tetapi Ma'kerang juga harus meningkatkan lagi bauran pemasaran agar berada di kategori baik.

Kelayakan bisnis Ma'kerang ditinjau dari aspek manajemen dengan menilai perencanaan Ma'kerang memiliki perencanaan pemasaran yang baik, Ma'kerang memiliki perencanaan pembuatan produk baru walaupun waktunya tidak bisa tentukan dan Ma'kerang memiliki perencanaan untuk meningkatkan pengembangan sdm dengan cara meberikan pelatihan karyawan pada semua bidang seperti memasak. Penggorganisasian
Ma'kerang sudah terorganisasi baik, semua keputusan atas dasar dari manajer, setiap karyawan selalu melakukan pendelegasian saat pergantian shift agar pekerjaan untuk shift selanjutnya jelas, dan pembagian kerja karyawan di Ma'kerang sudah sesuai dengan bagiannya dan pembaiannya adil tetapi terkadang jika Ma'kerang sedang ramai dan memang karyawan yang sedang operasional sedikit maka karyawan harus bisa membantu pekerjaan di bagian lain misalnya bagian kasir membantu melayani konsumen atau memasak. Pelaksanaan Ma'kerang belum baik karena manajer jarang memberikan pengarahan. Dan pengawasan Ma'kerang sudah baik karena manajer selalu mengawasi karyawan dan karyawan selalu mengawasi kualitas produk sebelum diberikan kepada konsumen. Dapat disimpulkan bahwa dalam aspek manajemen Ma'kerang layak untuk dijanlankan.

Kelayakan bisnis Ma'kerang ditinjau dari aspek teknis/operasi berdasarkan penilaian lokasi, luas produksi, tata letak 
produksi, dan kelengkapan peralatan operasional. Luas produksi Ma'kerang hanya $5 \mathrm{~m} \times 3 \mathrm{~m}$ belum bisa membuat karyawan kerja dengan leluasa, tata letak produksi belum baik karena penataan peralatan belum rapih dan toilet pengunjung berapa di dalam kitchen sehingga pengunjung akan sering melewati dan bisa melihat kitchen Ma'kerang, walaupun peralatan operasional Ma'kerang sudah lengkap dan menucukupi tetapi tidak bisa menyatakan bahwa dalam aspek tenis/operasi Ma'kerang layak, karena bagian terpenting dari seperti luas produksi dan tata letak produksi Ma'kerang belum bisa dikatakan baik maka dalam aspek teknis/operasi Ma'kerang tidak layak.

Kelayakan bisnis Ma'kerang ditinjau dari aspek hukum yang menilai badan hukum, izin-izin yang dimiliki, dan sepertifikat tanah. Ma'kerang merupakan perusahaan pribadi, sampai saat ini belum memiliki izin usaha dari pemerintah, dan hanya baru memiliki izin dari RT/RW saja, dan Ma'kerang tidak memiliki sertifikat tanah karena status dari tempat Ma'kerang adalah sewa. Sehingga dapat disimpulkan dalam aspek hukum Ma'kerang tidak layak.

5. Kelayakan bisnis Ma'kerang ditinjau dari aspek ekonomi dan sosial yang menilai dampak ekonomi dan dampak sosial. Ma'kerang tidak memberikan dampak perubahan pada perekonomian warga sekitar, dan perekonomian pemerintah karena Ma'kerang belum terkena pajak pemerintah. Ma'kerang tidak memberikan dampak perubahan demografi, perubahan budaya dan perubahan bagi kesehatan.

6. Kelayakan bisnis Ma'kerang ditinjau dari aspek keuangan yang dihitung berdasarkan metode penilaian investasi payback period3 bulan 80 hari maka usaha layak untuk dijalankan, Net present value (NVP) 34,514,085 > 40,520,500 sehingga tidak dapat diterima dan tidak layak, Internal rate of return (IRR) $67 \%>5,25 \%$ sehingga layak untuk diteruskan, dan Profitability Index (PI) $1.839>1$ sehinggadapat diterima dan layak.
Berdasarkan dari semua metode penilaian investasi Ma'kerang berada pada katogori baik dan layak sehingga dapat disimpulkan bahwa dalam aspek keuangan Ma'kerang memang layak

\section{Daftar Pustaka}

Alama, B. (2011). Pengantar bisnis. Bandung: Alfabeta.

Alamsyah, y. (2008). bangkitnya bisnis kuliner tradisional meraih untung dari bisnis makanan tradisional. jakarta: PT. Elex Media Komputindo.

Arief, A. r. (2005). Pengantar Ilmu Perhotelan dan Restoran. Yogyakarta: Penerbit Graha Ilmu.

Arikunto, S. (2009). Manajemen Penelitian. Jakarta: PT Rineka Cipta.

Baddi Hidayat, Lusi Triyani, Siti Hanifah. (2009). Peta 100 Tempat Jajan dan Makanan Legendaris di Bandung. Jakarta: Gramedia.

Cahyani, a. (2005). Strategi dan Kebijakan Manajemen Sumber Daya Manusia. Jakarta: PT Indeks.

Diarta, I. G. (2009). Pengantar ilmu pariwisata. yogyakarta: Andi.

Happy Marpaung, D. S. (2000). Pengetahuan Kepariwisataan. Bandung: ALFABETA.

Hendrayana, M. (2011). Strategi Pengembangan Makanan Tradisional di Bali pada Hotel kawasan sanur. Denpasar: Universitas Udayana.

Hunger, J. D., \& Wheelen, T. L. (2003). Management Strategis. Yogyakarta: Andi.

Hurriyati, R. (2010). Bauran Pemasaran \& Loyalitas Konsumen. Bandung: ALFABETA.

Ibrahim, Y. (2009). Studi kelayakan bisnis. Jakarta: Rineka cipta.

Ibrahim, Y. (2009). Studi kelayakan bisnis edisi revisi. Jakarta: PT rineka cipta.

Johan, S. (2011). Studi Kelayakan Pengembangan Bisnis. Yogyakarta: GRAHA ILMU.

Kasmir dan Jakfar. (2012). Studi kelayakan bisnis. jakarta: prenada media grup. 
Khodayat. (1998). Sejarah Pariwisata dan Perkembangannya di Indonesia. jakarta: Grasindo.

Kotler, P. (1992). Manajemen Pemasaran. Jakarta: Erlangga.

Mahadewi, I. g. (2012). Metodologi Penelitian. Yogyakarta: Andi.

Marpaung, h. (2000). Pengetahuan Kepariwisataan. Bandung: ALFABETA.

Marsum, W. A. (2005). Restoran dan Segala Permaslahan. yogyakarta: ANDI.

Martono, N. (2011). Metode Penelitian Kuantitatif. Jakarta: PT Rajagrafindo Persada.

Minantyo, H. (2011). Dasar-dasar Pengolahan Makanan (Food Product Fundamental). Yogyakarta: Graha Ilmu.

Neufert, E. (2002). Data Arsitek . Jakarta: Erlangga.

Purnaya, I. G. (2016). Ekonomi dan Bisnis. Yogyakarta: ANDI.

Puryanto, d. (2014). SPSS 22 : Pengolahan Data Praktis. Yogyakarta: Andi.

Sgugiyono. (2011). Metode Penelitian Kuantitatif, Kualitatif, Dan Kombinasi (Mix Methods). Bandung: ALFABETA.

Soekresno. (2000). Manajemen Food and Beverage . Jakarta: Gramedia Pustaka Utama.

Suganda, H. (2011). Wisata Paris Van Java. Bandung: PT Kompas Media Nusantara.

Sugiyono. (2014). Metode Penelitia Kuantitatif kualitatif dan R\&D. Bandung: Alfabeta.

Sugiyono. (2008). Metode Penelitian Kuantitatif Kualitatif dan R\&D. ALFABETA.

Sujarweni, V. W. (2014). SPSS untuk penelitian. Yogyakarta: Pustaka Baru Press.

Supomo, I. (1999). Metodologi Penelitian Bisnis Untuk Akutansi dan Manajemen. Yogyakarta: BPPE Yogyakarta.

Tika, M. P. (2006). Metodologi Riset Bisnis.
Jakarta: PT Bumi Aksara.

Umar,H. (2003). Metode Riset Bisnis. Jakarta: Gramedia Pustaka Utama.

Umar,H. (2002). Riset Pemasaran dan Perilaku Konsumen. Jakarta: PT Gramedia Pustaka Utama.

Umar, H. (2003). Studi kelayakan dalam bisnis. Jakarta: Gramedia Pustaka utama.

Wardiyanta. (2006). Metode Penelitian Pariwisata. Yogyakarta: ANDI.

Widjojo, A. M. (2005). Restoran dan Segala Permasalahannya. Yogyakarta: ANDI.

Zeithaml, Bitner, Gremler. (2013). Services Marketing: Integrating Customer Focus Across the firm 6th ed. Mc.Graw-Hill: Boston. 